\title{
Efficiency of solar and wind energy use in the countries of Central and North-East Asia
}

\author{
Oleg Marchenko ${ }^{1, *}$ and Sergei Solomin ${ }^{1}$ \\ ${ }^{1}$ Melentiev Energy Systems Institute of Siberian Branch of the Russian Academy of Sciences, Irkutsk, Russia
}

\begin{abstract}
This paper investigates the effectiveness of renewable energy sources using solar and wind energy in the countries of Central and North-East Asia. The analysis was carried out in two stages. At the first stage, the efficiency of wind and solar installations in different climatic conditions was compared by the criterion of the cost of electricity. At the next stage of analysis, an optimization mathematical model was used to study the system that simultaneously includes wind and solar installations, backup energy sources and batteries. The model takes into account system effects caused by the interaction of the system elements between themselves and with the environment. It solves the problem of mathematical programming - the search for the minimum of the objective function (total costs) at some constrains. The model is used to study the economic efficiency of the large-scale construction of solar power plants in the Gobi Desert. It is shown that the joint use of solar and wind energy gives a positive economic effect, i.e. energy cost are less than with separate use of these energy sources. Under suitable wind conditions such systems reduces the cost of electricity by more than a quarter compared to the option of using solar energy only.
\end{abstract}

\section{Introduction}

Many countries are implementing activities aimed at reducing greenhouse gas emissions. This reduces the negative impact of energy on the climate system. 77 countries announced their commitment to net zero carbon emissions by 2050. In this regard, great importance is attached to the development of renewable energy sources (RES) [1, 2]. By the end of 2019, 166 countries had renewable power targets [3]. Among renewable energy sources, solar and wind energy are developing at the fastest rates [3, 4]. In the period from 2009 to 2019 installed capacity of wind power plants (WPP) has grown more than in 4 times (average growth rate more than $15 \%$ ), and solar power stations (SPP) more than in 26 times (just under $40 \%$ per year) (Fig. 1).

The installed capacity of solar power plants based on solar photovoltaics increased by $115 \mathrm{GW}$ in 2019 and reached $627 \mathrm{GW}$, and the capacity of concentrating solar thermal power plants is slightly more than $6 \mathrm{GW}$. The installed capacity of wind power plants increased by 60 GW and reached $651 \mathrm{GW}(621 \mathrm{GW}$ onshore and about $30 \mathrm{GW}$ offshore). Wind turbines (WT) produce about $6 \%$ of the world's electricity, solar photovoltaics (PV) produce about $3 \%$ [3].

By the end of 2019, at least 39 countries had a cumulative solar PV capacity of $1 \mathrm{GW}$ or more. The number of countries with some level of wind power capacity exceeded 102, and 35 countries had more than 1 GW in operation [3]. $a$

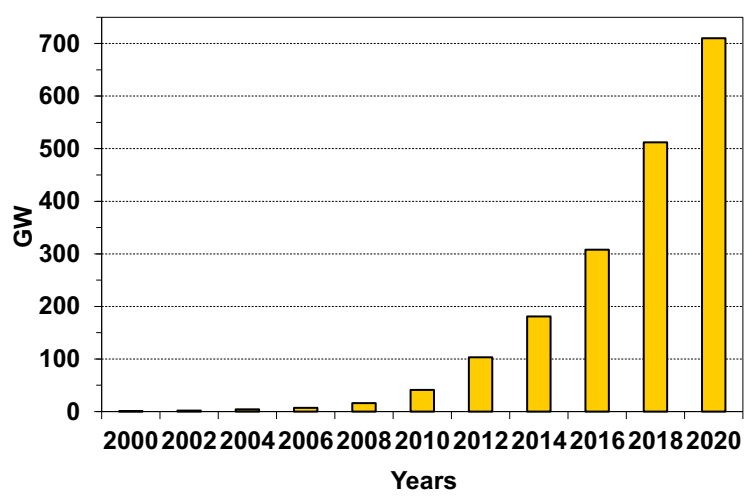

$b$

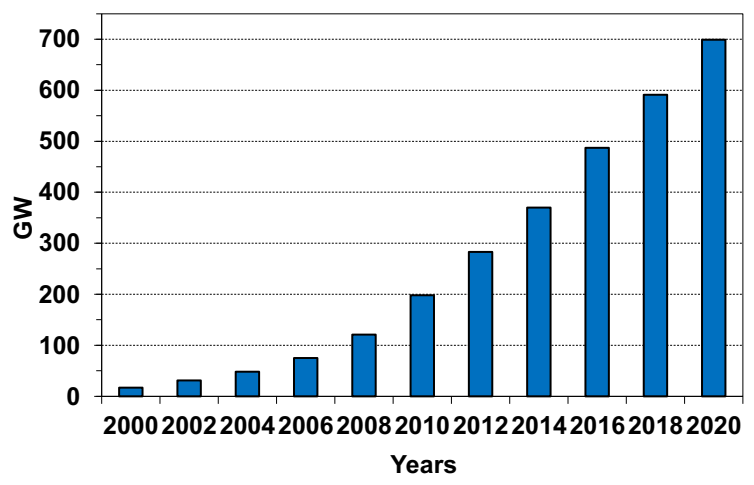

Fig. 1. Installed capacity of SPP $(a)$ and WPP $(b)$ in the world by years, GW (forecast for 2020).

\footnotetext{
* Corresponding author: $\underline{\text { marchenko@isem.irk.ru }}$
} 
In 2020 the installed capacities of both the solar power plants and the wind power plants will exceed about $700 \mathrm{GW}$. According to the forecasts of the International energy Agency, in the period 2019-2024, the RES capacity will increase by 1200-1500 GW (including 700-880 GW of PV) [5].

The crisis associated with the novel coronavirus (COVID-19) slowed the growth rate of solar and wind power in the first half of 2020. Some projects hit by labour and supply chain disruptions. However, as the consequences of the crisis are overcome, it is highly likely that the growth rate of solar and wind energy will be restored.

The cost of electricity from solar and wind power sources have fallen sharply over the past decade (especially for PV). Solar and wind power generation technologies have become the cheapest option for new capacity in almost many parts of the world [6].

Currently, the issues of electric power integration of producers and consumers of electric energy in different regions of the world are being actively discussed [7, 8]. It is expected that between Russia and Asian countries (Fig. 2) interstate electrical connections will develop, which can provide both economic and environmental effects, including due to the large-scale introduction of renewable energy sources $[9,10]$.

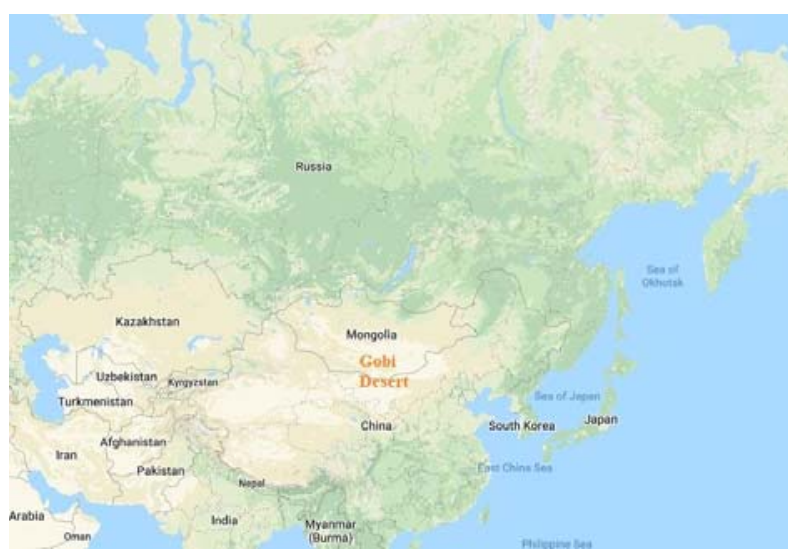

Fig. 2. Russia and neighboring Asian countries (Google Maps).

The most promising direction of interstate electric communications development for Russia is the southern one, which provides for the integration of electric power systems of Russia, Central Asia and North-East Asia [9, 11]. At the same time, there are quite favorable conditions for the development of solar and wind energy in this region.

One of the projects under discussion involves largescale construction of wind and solar power plants in the Gobi Desert and subsequent export of electricity to neighboring countries $[12,13]$.

The Gobi is the third largest desert in the world. It stretches $1,600 \mathrm{~km}$ from southwest to northeast and 800 $\mathrm{km}$ from north to south. The area of the desert is $1.3 \mathrm{mln}$ $\mathrm{km}^{2}$. The distance to the Mongolian capital Ulaanbaatar is about $400 \mathrm{~km}$, to the Chinese capital Beijing about $700 \mathrm{~km}$.

Information on the use of renewable energy in the countries of Central and North-East Asia is presented in
Table 1. The world leaders in the use of solar and wind energy are the countries of North-East Asia, especially China (about a third of the installed capacities of solar and wind power plants). In Central Asia, solar and wind power plants are being built only in Kazakhstan and Uzbekistan.

Table 1. Capacity of RES (2019), GW [3, 4].

\begin{tabular}{|l|r|r|r|}
\hline Country & \multicolumn{1}{|c|}{$\begin{array}{c}\text { Solar } \\
\text { energy }\end{array}$} & $\begin{array}{c}\text { Wind } \\
\text { energy }\end{array}$ & $\begin{array}{c}\text { RES*, } \\
\text { total }\end{array}$ \\
\hline World & 633 & 651 & 2588 \\
\hline Russia & 1 & $<1$ & 55 \\
\hline Asia & 331 & 283 & 1150 \\
\hline including & & & \\
\hline China & 205 & 236 & 790 \\
\hline Taiwan & 4 & 1 & 7 \\
\hline Japan & 63 & 4 & 98 \\
\hline N. Korea & 0 & 0 & 5 \\
\hline S. Korea & 11 & 2 & 16 \\
\hline Mongolia & $<1$ & $<1$ & $<1$ \\
\hline NEA,total & 283 & 243 & 916 \\
\hline Kazakhstan & $<1$ & $<1$ & 4 \\
\hline Kyrgyzstan & 0 & 0 & 4 \\
\hline Tajikistan & 0 & 0 & 5 \\
\hline Turkmenistan & 0 & 0 & 0 \\
\hline Uzbekistan & $<1$ & $<1$ & 2 \\
\hline CA, total & $<1$ & $<1$ & 15 \\
\hline
\end{tabular}

Note: * including other types of RES (hydropower, biomass, geothermal and marine energy). NEA is North-East Asia, CA is Central Asia.

The countries of North-East Asia plan to increase the share of RES in electricity generation primarily due to the development of solar and wind generation [3]. China should strengthen its position as a world leader in the use of wind and solar energy (up to $40 \%$ of the new installed capacity in the world in the next five years). New tens of gigawatts of installed capacity will be introduced by 2025 in Japan, Korea, Taiwan (Chinese Taipei). Mongolia also has ambitious targets to develop solar and wind generation (Table 2).

Table2. National targets for renewable share of electricity generation [3].

\begin{tabular}{|l|c|c|c|}
\hline \multirow{2}{*}{ Country } & \multicolumn{2}{|c|}{ Share, \% } & \multirow{2}{*}{ Year } \\
\cline { 2 - 3 } & $\begin{array}{c}\text { Status in } \\
\mathbf{2 0 1 8}\end{array}$ & Target & \\
\hline China & 27 & 35 & 2030 \\
\hline Taiwan & 5 & 20 & 2025 \\
\hline Japan & 8 & 24 & 2030 \\
\hline S. Korea & 6 & 35 & 2030 \\
\hline Mongolia & 0 & 30 & 2030 \\
& 0 & 100 & 2050 \\
\hline Kazakhstan & 2 & 50 & 2030 \\
\hline Tajikistan & 0 & 10 & no date \\
\hline Uzbekistan & 13 & 20 & 2025 \\
\hline
\end{tabular}

Kazakhstan has set a target to increase the share of renewable energy sources in electricity generation to $3 \%$ in 2018 and $50 \%$ in 2030. In the near future, it is planned to increase the installed capacity to $0.8 \mathrm{GW}$ at 28 solar stations and $1.8 \mathrm{GW}$ at 34 wind stations. 
Uzbekistan plans to install $1.2 \mathrm{GW}$ of solar power plants and $0.3 \mathrm{GW}$ of wind power plants by 2025 [3].

\section{Statement of the problem and description of the method}

The goal of the present research is to assess the competitiveness of various types of power plants and the impact of carbon dioxide emission constraints on it, as well as to determine the optimal structure of wind-solar power plants for different combinations of economic and climatic conditions of Russia and neighboring countries of Central and North-East Asia.

The solution to the problem is proposed to be divided into two stages. At the first stage, the unit cost of electricity production (the cost of electricity) for various types of energy sources were determined [6, 14, 15]. This allows you to pre-evaluate and compare their economic efficiency. When calculating the cost of electricity, individual plants are considered and it is assumed that all energy is fully used.

The cost of energy is equal to the unit cost of energy production and at the same time represents its minimum price at which the energy supply project remains efficient. The cost of electricity can be represented as the sum of terms that take into account the cost of construction and operation, the fuel cost and the carbon cost $[15,16]$ :

$S=\left[F \frac{e^{\sigma \Delta T}-1}{\sigma \Delta T}+\mu\right] \frac{k}{C F \cdot H \cdot(1-\beta)}+\frac{p}{8.15 \cdot 10^{3} \eta}+\frac{a p^{*}}{8.15 \cdot 10^{3} \eta}$.

The first component of the cost of electricity is directly proportional to the specific investment $k$, inversely proportional to the capacity factor $C F$ (in the above formula $\mathrm{H}=8760$ hours/year) and depends on the capital recovery factor $F$, the annual discount rate $d$, the construction time $\Delta T$, lifetime $T$, the annual fixed costs $\mu$ and energy consumption for own needs $\beta[15,16]$.

The fuel component is directly proportional to the fuel price $p$ and inversely proportional to the efficiency $\eta$. The emission component depends on emission factor $a$ and carbon tax $p^{*}[14,16]$. PV and WT have no fuel and emission components.

At the second stage, mathematical model was used that takes into account the system effects that occur when energy sources interact with each other and with the environment, additional conditions and constrains.

The optimal structure of the power supply system was chosen from the solution of the mathematical programming problem: minimizing the total (reduced to a year) discounted costs for the creation and operation of the system, taking into account the balances of primary, secondary and final energy and a number of additional constrains. These include constrains, for example, on power consumption levels, on the installed capacity of energy sources to back-up RES stochastic generation, battery operation modes, etc.

For calculations, the mathematical model REM-2 was used. The model takes into account changes in electricity generation from solar and wind installations by the hours of the day and the seasons of the year. The variability in the time of energy production of renewable energy makes their joint use reasonable. The model is described in detail in $[17,18]$.

In Fig. 3 the power supply system is considered. It consists of photovoltaic converters (PV), wind turbines (WTs) with the possibility of short-term accumulation of electricity. The system includes battery charge controllers, voltage converters and network interface devices (network inverters) and a back-up energy source, conventionally called "Network" (Grid).

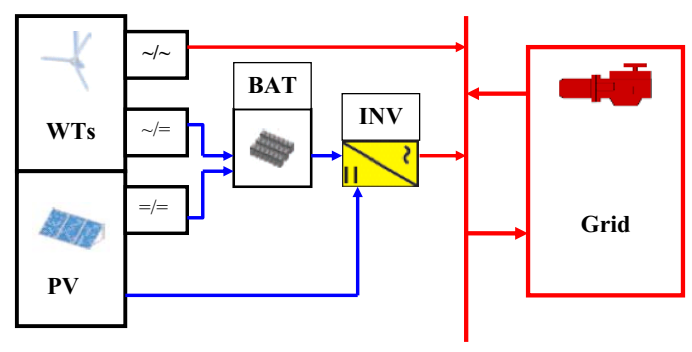

Fig. 3. Diagram of the power system. WTs - wind turbines, PV - photovoltaic, BAT - batteries, INV - inverter, Grid network, back-up energy sources.

At certain points in time photovoltaic converters and wind turbines can be in an idle state, moreover, these moments in some cases may coincide (period of energy "standstills"). At other times, they produce surplus electricity for a power system with a limited load level.

In this regard, it is assumed that at any time the electric power system (the "Network") is able to supply electrical energy to system at a given price and is able to accept surplus electricity generated by renewable energy sources. Surplus electricity is sold to the grid at the same price.

\section{Initial data}

The economic efficiency and competitiveness of PV and WT are determined primarily by the technical and economic indicators of power plants, the price of electricity of a backup energy source and the capacity factor. The variation of capacity factor for solar cells depends on the arrival of solar radiation on the surface of the solar panel, and for wind turbines it depends on the wind speed at the height of the rotor blade $[15,19,20]$. It is assumed that PVs have optimal tilted solar panels with the corresponding tracking system for the Sun, and the WT tower height exceeds $100-120 \mathrm{~m}$.

Tables 3 and 4 show the initial data. The uncertainty interval of the initial data is formed on the basis of information from $[6,12,13,15,16,18,19]$. The discount rate is assumed to be $5 \%$, lifetime is 25 years. 
Table 3. Technical and economic indicators of solar power plants.

\begin{tabular}{|c|c|c|c|}
\hline $\begin{array}{c}\text { Region / } \\
\text { country }\end{array}$ & $\boldsymbol{k}, \mathbf{\$} / \mathbf{k W}$ & $\boldsymbol{\mu}, \mathbf{6}$ & $\mathbf{C F}$ \\
\hline $\begin{array}{c}\text { Siberia and Far East } \\
\text { (Russia) }\end{array}$ & $1500-2000$ & $1.5-2.0$ & $0.11-0.17$ \\
\hline Mongolia & $1100-1400$ & $1.5-2.0$ & $0.15-0.24$ \\
\hline China & $1000-1300$ & $1.5-2.0$ & $0.15-0.25$ \\
\hline Korea & $1800-2300$ & $1.5-2.0$ & $0.15-0.17$ \\
\hline Japan & $2000-2500$ & $1.5-2.0$ & $0.14-0.16$ \\
\hline Central Asia & $1100-1400$ & $1.5-2.0$ & $0.16-0.25$ \\
\hline
\end{tabular}

Table 4. Technical and economic indicators of wind power plants.

\begin{tabular}{|c|c|c|c|}
\hline $\begin{array}{c}\text { Region / } \\
\text { country }\end{array}$ & $\boldsymbol{k}, \mathbf{\$} / \mathbf{k W}$ & $\boldsymbol{\mu}, \mathbf{\%}$ & $\mathbf{C F}$ \\
\hline $\begin{array}{c}\text { Siberia and Far East } \\
\text { (Russia) }\end{array}$ & $1500-2000$ & $2.0-2.5$ & $0.18-0.48$ \\
\hline Mongolia & $1300-1600$ & $2.0-2.5$ & $0.18-0.42$ \\
\hline China & $1300-1500$ & $2.0-2.5$ & $0.22-0.59$ \\
\hline Korea & $1500-1700$ & $2.0-2.5$ & $0.23-0.32$ \\
\hline Japan & $1600-1800$ & $2.0-2.5$ & $0.20-0.37$ \\
\hline Central Asia & $1300-1500$ & $2.0-2.5$ & $0.18-0.36$ \\
\hline
\end{tabular}

\section{Calculation results and their analysis}

Fig. 4 shows the values of the cost of electricity for thermal power plants (TPPs) using fossil fuels (minimum for coal or gas TPPs) and for renewable energy sources. It can be seen that, taking into account the charge for carbon dioxide emissions, the intervals of uncertainty in the cost of electricity from thermal, wind and solar power plants intersect. This indicates that, under certain conditions, wind farms and solar power plants are competitive with fossil fuel power plants.

In North-East Asian countries, the cost of electricity for organic fuel power plants under construction is usually $3-10$ cents/kWh, in the Eastern regions of Russia and Central Asia, it does not exceed 4-8 cents/kWh. Under favorable conditions for solar and wind power plants, the cost of their electricity $(3-5$ cents $/ \mathrm{kWh})$ is less than the costs of electricity from competing thermal power plants (coal, gas, liquid fuel). Under less favorable conditions, RES requires the introduction of special tariffs and other measures to encourage investors, in particular, the establishment of a fee for greenhouse gas emissions (carbon tax) [14, 15, 21].
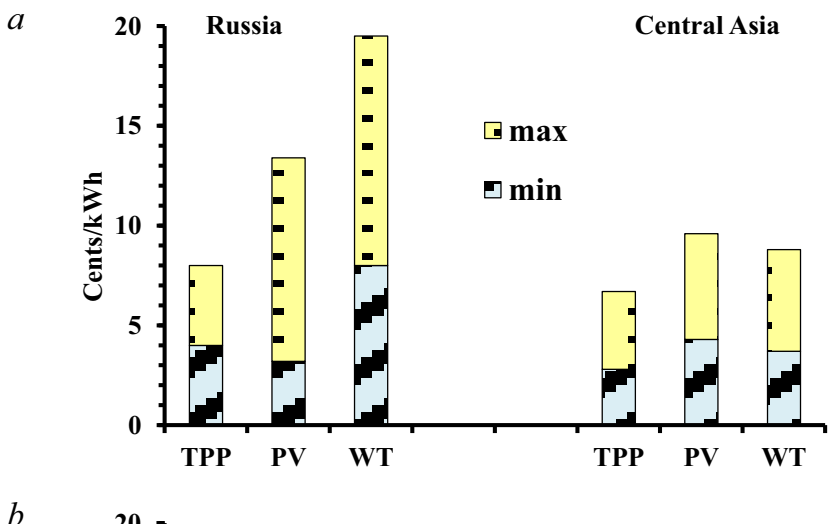

$b$

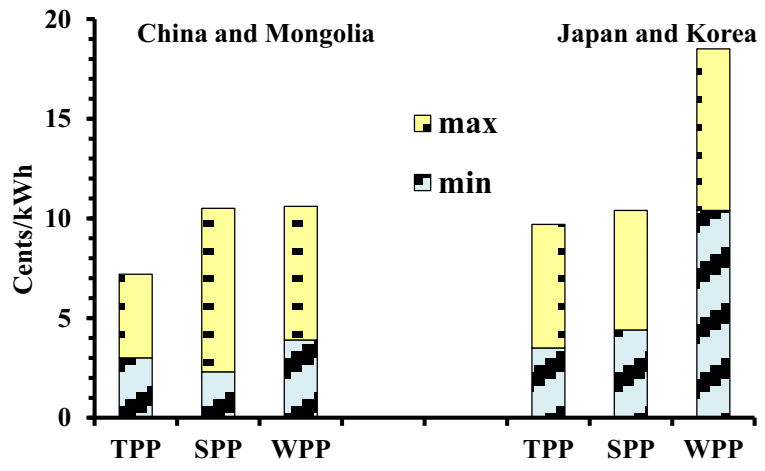

Fig. 4. Comparison of cost of electricity for Eastern Russia and Central Asia (a) and North-East Asia (b). TPP - thermal power plants, SPP - solar power plants, WPP - wind power plants.

The most favorable conditions for the construction of wind turbines are characteristic of China (Tibet), where the capacity factor can reach 0.59 [19]. On the territory of the Russian Far East (the Pacific coast) and Mongolia (the Mongolian part of the Gobi Desert) there are also favorable conditions for the development of wind energy. In Korea and Japan, wind turbines can also be competitive due to high tariffs in the energy systems of these countries. The good conditions for the construction of PV are characteristic of the southern regions of China and Mongolia, in particular, the Gobi Desert [13, 20, 22].

To study energy systems that simultaneously include PV, WT, backup energy sources and batteries, an optimization mathematical model is used.

Fig. 5 shows the results of calculating the optimal power generation ratio between a PV and a WT on the REM-2 model at different prices of electricity from a network backup source and different climatic conditions. The following tariffs are typical for the regions: 4-5 cents/kWh in Central Asia, 6 cents/kWh in Russia and 8-29 cents/kWh in North-East Asia (China and Japan respectively) [23]. The characteristics of solar radiation and wind given in the corresponding editions of climate reference books for Russia (RU), Central Asia (CA) and North-East Asia (NA) were used. The Northern (North) 
and southern (South) regions are considered separately. At the same time, territories with the best conditions for solar and wind energy use were selected for each of the regions.

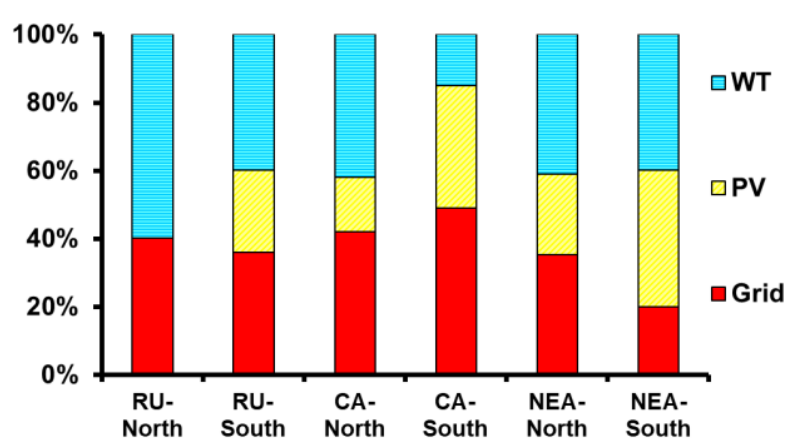

Fig. 5. Optimal ratios of power generation.

With cheap energy from the network, the use of PV and wind turbines is not required. At a higher price, the joint use of solar and wind energy is effective.

As solar radiation increases from northern to southern, the role of solar cells increases. In the northern regions of Russia (RU-North) (the arrival of solar radiation does not exceed $1200 \mathrm{kWh} / \mathrm{m}^{2}$ per year) the use of solar cells is impractical, and the main part of the generation is provided by wind turbines. In the southern regions (RU-South), with an increase in insolation to $1400 \mathrm{kWh} / \mathrm{m}^{2}$ per year and a decrease in the average long-term wind speed from 7 to $6 \mathrm{~m} / \mathrm{s}$, the role of solar cells and a backup energy source increases.

In Central Asia, three energy sources are included in the optimal plan; as the amount of solar radiation increases, the optimal proportion of solar cells increases. Given that the price of electricity in this region does not exceed 5 cents per $\mathrm{kWh}$, the role of the network backup source is relatively large. As electricity tariffs increase, the role of wind farms (in the northern regions) and solar power stations (in the southern regions) will increase and the role of a backup source of electricity will decrease.

In the southern regions of North-East Asia, the conditions for the development of solar and wind energy are among the best in the world $[19,20]$, therefore, the share of the duplicate source is minimal.

Below are the calculations for the conditions of the Gobi Desert. It is assumed that the complex of windsolar power plants in this area will represent one of the first stages of the electric power integration of the countries of North-East Asia. It works for consumers who, along with electricity from renewable energy sources, also consume electricity from systems in North and North-East China, which compensate for the uneven generation of renewable energy sources. The power of these electric power systems is much greater than the power of the wind-driven power plants under consideration.

The amount of solar radiation arrival in the Gobi desert varies in a fairly narrow range and is acceptable for the development of solar energy. Wind conditions vary over a wide range. In some places, the wind conditions are good, in others they are bad and obviously not suitable for the effective use of wind turbines.

Fig. 6 shows the data for calculating the optimal ratio of power generation between PV and WT at different electricity prices in the power system and under different climatic conditions. The price of electricity varied in the range of $5-15$ cents $/ \mathrm{kWh}$ to account for the uncertainty of future conditions. In particular, the price of electricity may increase with the introduction of a carbon tax $[16$, 21].
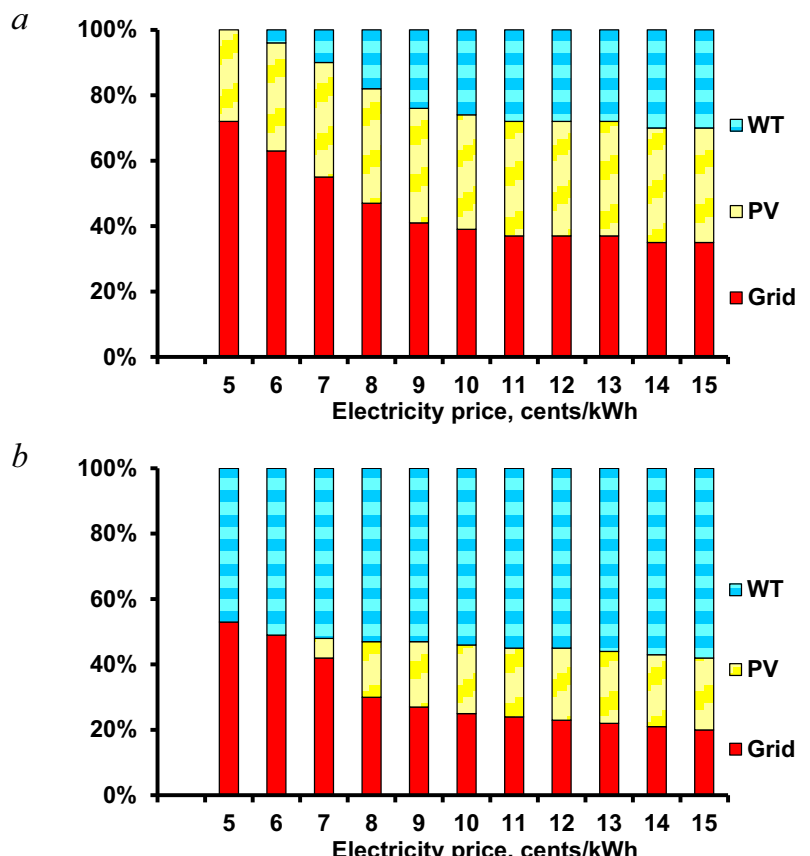

Fig. 6. Share of energy sources in electricity production at different prices of electricity from the network and climatic conditions $\left(a-\mathrm{Q}=1650 \mathrm{kWh} / \mathrm{m}^{2} /\right.$ year and $\mathrm{V}=3.5 \mathrm{~m} / \mathrm{s} ; b-$ $\mathrm{Q}=1600 \mathrm{kWh} / \mathrm{m}^{2} /$ year and $\mathrm{V}=5.5 \mathrm{~m} / \mathrm{s}$ ) ( $\mathrm{Q}$ is the annual solar radiation input on a horizontal surface, $\mathrm{V}$ is average long-term wind speed at a standard height of $10 \mathrm{~m}$ ).

With cheap energy from the network (less than 4 cents/kWh), the use of solar cells and wind turbines is not required. In areas with a large influx of solar radiation and poor wind conditions (Fig. 6,a) with the increase in the price of electricity, the use of solar modules becomes economically effective. At a price above 5 cents $/ \mathrm{kWh}$, the joint use of solar and wind energy is effective. With an increase in the price of electricity, the share of wind turbines in the total generation increases, which is due to the advisability of replacing the expensive energy of the power system with cheaper energy of wind turbines.

In areas with good wind conditions (Fig. 6, b), the use of wind energy is a priority (the cost of wind energy is less than the same indicator for PV). As the price of electricity rises, installed capacity and production of WT and PV increase.

The dependence of the share of energy sources in energy supply of consumers on the average long-term wind speed for wind turbines is shown in Fig. 7 at a price of electricity from the network of 8 cents/kWh (the price of electricity in the power system of China). 
In areas with low average annual wind speeds, only solar energy are used. In areas with an average long-term wind speed (at $10 \mathrm{~m}$ height) of $4 \mathrm{~m} / \mathrm{s}$, the optimal power of the solar cells and wind turbines are approximately equal, the differences in power generation are more significant. At an average long-term wind speed of 5-6 $\mathrm{m} / \mathrm{s}$, the share of renewable energy increases to $70-75 \%$, and the joint use of solar and wind energy allows reducing the total costs of the power supply system by $26-28 \%$ compared with the option of using only solar energy (Fig. 8).

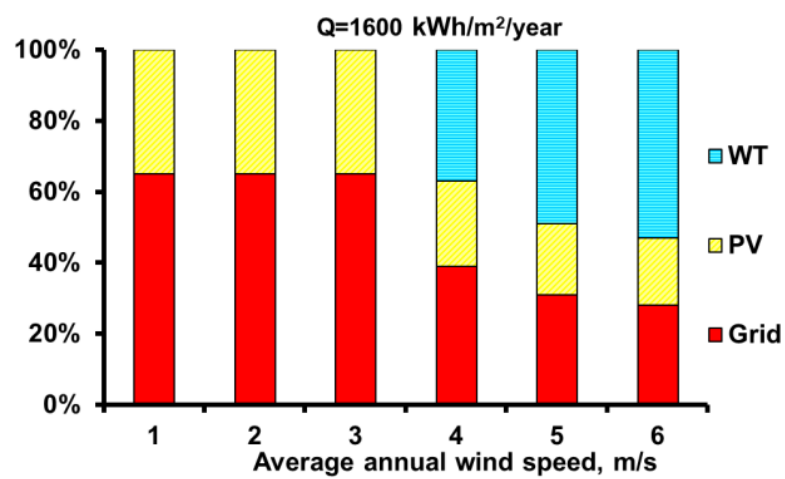

Fig. 7. Dependence of energy sources share in electricity generation on average long-term wind speed (with the price of electricity from the network of 8 cents $/ \mathrm{kWh}$ ).

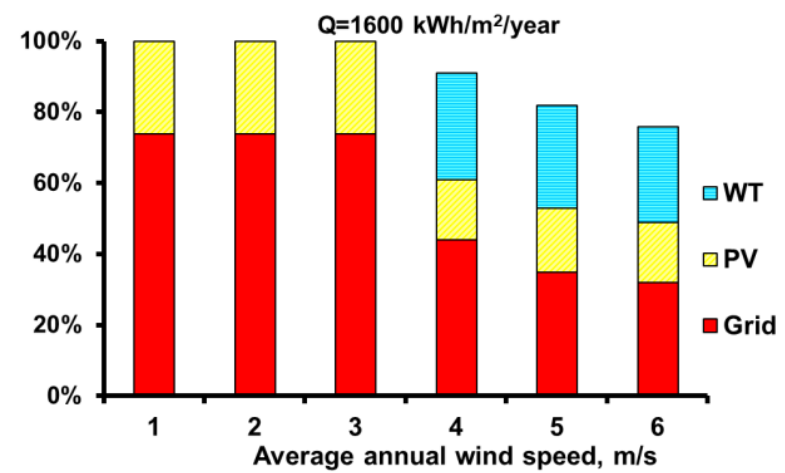

Fig. 8. Dependence of relative costs for electricity supply on average long-term wind speed (with the price of electricity from the network of 8 cents $/ \mathrm{kWh}$ ).

\section{Conclusions}

A comparison of renewable and non-renewable energy sources by the criterion of the cost of generated electricity is carried out. Under favorable conditions, PV modules and wind turbines in a number of regions can generate cheap electricity at a cost of $3-5$ cents $/ \mathrm{kWh}$. It is shown that taking into account the payment for emissions, renewable energy sources can be competitive in the energy markets (under certain conditions).

An additional comparison of different types of energy sources, taking into account system effects, was performed using the REM-2 (Renewable Energy Model) mathematical model. The calculations showed the efficiency of the joint use of solar and wind energy and allowed us to identify the optimal share of solar cells and wind turbines for a combination of different conditions in the regions of Central and North-East Asia.
The economic efficiency of the joint use of solar and wind energy in the Gobi Desert is shown, with the exception of some areas with low average long-term wind speeds. The optimal share of renewable energy is $70-75 \%$ with an average long-term wind speed of 5-6 $\mathrm{m} / \mathrm{s}$ (at $10 \mathrm{~m}$ height). With the joint use of wind and solar energy, you can reduce the electricity cost by more than a quarter compared with the option of using solar energy only.

\section{Acknowledgement}

The research was carried out under State Assignment, Project III.17.6.2 (reg. no. AAAA-A17-117030310447-3) of the Fundamental Research of Siberian Branch of the Russian Academy of Sciences.

\section{References}

1. L.S. Belyaev, O.V. Marchenko, S.V. Solomin, Int. J. of Energy Technology and Policy 3, 324-341 (2005)

2. L.S. Belyaev, O.V. Marchenko, S.P. Filippov, S.V. Solomin, Int. J. of Global Energy Issues 25, 94-108 (2006)

3. Renewables 2020 Global Status Report, (REN21, Paris, 2020)

4. Renewable Energy Statistics 2020, (IRENA, Abu Dhabi, 2020)

5. Renewables 2019. Analysis and forecasts to 2024, (IEA, Paris, 2019)

6. Renewable Power Generation Costs in 2019, (IRENA, Abu Dhabi, 2020)

7. Z. Liu, Global energy interconnection, (London, Elsevier Academic Press, 2015)

8. N.I. Voropai, S.V. Podkovalnikov, 2019 Twelfth International Conference "Management of largescale system development" (MLSD), 8911062 (2019)

9. O.V. Marchenko, S.V. Podkovalnikov, V.A. Savelyev, S.V. Solomin, L.Y. Chudinova, World Economy and International Relations 62, 18-29 (2018)

10. D. Bogdanov, C. Breyer, Energy Conv. and Management, 112, 176-190 (2016)

11. L.Y. Chudinova, S.V. Podkovalnikov, I.L. Trofimov, International Multi-Conference on Industrial Engineering and Modern Technologies (FarEastCon), 8934226 (2019)

12. T. Otsuki, A.B. Mohd Isa, R.D. Samuelson, Energy Policy 89, 311-329 (2016)

13. T. Otsuki, Renewable Energy 108, 321-335 (2017)

14. Projected costs of generating electricity, (IEA/NEA, Paris, 2015)

15. O.V. Marchenko, S.V. Solomin, E3S Web of Conferences 114, 05001 (2019)

16. O.V. Marchenko, S.V. Podkovalnikov, S.V. Solomin, International Multi-Conference on 
Industrial Engineering and Modern Technologies (FarEastCon), 8934359 (2019)

17. O.V. Marchenko, Int. J. of Low-carbon Technologies, 10, 250-255 (2010)

18. O.V. Marchenko, S.V. Solomin, Int. J. of Renewable Energy Research 7, 1561-1569 (2017)

19. C. Breyer, D. Bogdanov, K. Komoto, T. Ehara, J. Song, N. Enebish, Jap. J. of Applied Physics 54, 118 (2015)

20. M. Fasihi, C. Breyer, J. of Cleaner Production 243, 118466 (2020)

21. State and Trends of Carbon Pricing 2020, (World Bank, Washington, 2019)

22. S. Batmunkh, V. Stennikov, B. Bat-Erdene, A. Erdenebaatar, E3S Web of Conferences 27, 01006 (2018)

23. Electricity prices around the world, (GlobalPetrolPrices.com, 2020). Available at: https://www.globalpetrolprices.com/electricity_price s (https://archive.md/ly52E) (Accessed 25 July 2020). 